\title{
The Effect Of Strategic Management, Organizational Commitment And Organizational Culture On Employees 'Work Achievement In Higher Education Muhammadiyah Indonesia
}

\author{
Rustamadji \\ Che Mohd Zulkifli bin Che Omar \\ 1)Universitas Pendidikan Muhammadiyah Sorong \\ 2)Universiti Pendidikan Sultan Idris Malaysia \\ e-mail : rust_adji@yahoo.com
}

\begin{abstract}
This study examines the influence of three variables, namely strategic management of organizational commitment and organizational culture to work performance variable, and variable of three variables, namely strategic management of organizational commitment and organizational culture to sesame variable on employee at Muhammadiyah University of Indonesia. The sample used according to the calculation of cluster sampling probability proportionate to size model (PPS) with the formulation of Slovin obtained 386 employees at 12 muhammadiyah universities in Indonesia. The developed instrument combines part of the existing questionnaire related to strategic management, organizational commitment, and work performance, using the Likert Method of Successice Interval (MSI) scale. The data were analyzed by regression equation using SPSS 17 software. The regression equation is used to determine prediction how high the predictor variable value to the dependent variable. The use of regression analysis to test the hypothesis can be used if it meets the five underlying classical assumptions, namely normality, multicollinearity, heteroscedasticity, autocorrelation and linearity. Further testing hypothesis in this study using the $\mathrm{F}$ test, $\mathrm{T}$ test and Coefficient of Determination Test (R2). The results of this study concluded that strategic management of organizational and cultural commitment influences on employee performance, strategic management influence to organizational commitment, organizational commitment influence to strategic organization management culture, organizational commitment and organizational culture, together influence on employee performance. Strategic management, organizational commitment, organizational culture and employee performance have mutual interrelationships and mutual influence.
\end{abstract}

Keyword: strategic, commitment, culture, achievement, Muhammadiyah.

\section{Introduction}

The rapidly growing competition in businesses has urged organizations to focus on their employees and ensure their commitment to the workplace. Organizational commitment is regarded as one of the most important (Hanaysha, 2016). Competition is also happening in the business world of education. Teachers and education personnel as employees in universities, have a central role in developing the ability of universities in competing. Employees as human resources provide competitive advantage and flexibility in competition (Cavus M. F \& Saracoglu, T, 2014).

Highly committed and loyal employees are essential to achieving organizational goals. This is because employees with a higher level of commitment to the organization are perceived as more productive, harmonious, have better loyalty to their work, and have a higher responsibility and job satisfaction (Karim, F., \& Rehman, O., 2012 ). In addition, employees with strong organizational commitment tend to develop emotional attachment to their organization and are happy with greater aspirations to make meaningful contributions. An employee who is committed to his job and his career has little intention of taking leave or stops, tends to be satisfied with the job, and has higher intrinsic motivation (Sahoo, C. K., et al, 2010).

Job satisfaction and organizational commitment are influenced by compensation and benefits factors (Cavus M. F \& Saracoglu, T, 2014). Since the most important role in the realization of specific targets is given to humans, who are social beings, the achievement of organizational goals and activities depends on the presence of employees, who are closely tied to the values of the organization, are satisfied with the work and have adopted the goals and objectives of the organization As the goals and objectives of the employees themselves (Cavus MF \& Saracoglu, T, 2014). 
Employee empowerment begins with the concept of strategic conformity between people, tasks, technology, information processes, rewards and organizational structures where all must align before the organization can work efficiently. Employees with strong organizational commitment are emotionally tied to the organization and have a strong desire to contribute significantly to the success of the organization. This leads to increased competitiveness, accountability, risk taking, high innovation, low waste, and a desire to improve overall work performance. In addition, increased individual commitment and commitment to workgroups or teams improves team performance, interpersonal interaction, and improves individual performance and level of satisfaction. Empowerment thus inspires change and improves the level of work commitment that increases the level of individual employee commitment and helps achieve organizational goals (Sahoo C.K \& Das. $\mathrm{S}$, 2011). On the contrary, organizational commitment is not known whether it contributes to employee performance.

Employee performance is considered as an important in organization because it leads to the development of the organization effectively (Awadh A.M. \& Saad .MM, 2013). Employee loyalty is dependent on knowledge and awareness of the culture that enhances organizational behavior (Brooks, 2006). Previous research has shown a relationship between organizational culture and employee performance. Magee, (2002) argues that organizational culture is inherently linked to organizational practices which in turn affect employee performance. Hellriegel, D. \& Slocum, J. M., (2009) argue that organizational culture can improve employee performance if what supports it can be understood. Some theoretical models assert that an effective human resource system is based on a support value, which creates a positive impact on employee attitudes and behavior which in turn affect its performance (Ferris, G. R., et al, 1998). From various "organizational culture surveys" it has been claimed that employee performance can be improved by developing and creating some kind of organizational culture (Sackmanns, S. A. \& Bertelsmann S., 2006).

Even though Martin, J. \& Siehl, C., (1990) argue that organizational culture is theoretically related to performance and has a positive influence on it. Bowen, D. E., \& Ostroff, C., (1989) examine the role of culture in maintaining, maintaining and improving the performance of employees in the organization, but these studies have not led specifically to organizations engaged in education and mobile in developing countries such as Indonesia.

The rapidity of competition also brings about evolution in planning and thought processes to be able to defend the organization and win the competition (Zafar F. Babar S \& Abbas, H, 2013) The performance of business organizations in economic competition depends heavily on the quality of management through the adoption of appropriate strategic management Dess, et al., 2005).

Previous research on employee performance shows that management practices have a positive impact on employee performance (Hassan, 2016). Research on management of the organization has indeed been done as Chan has done (2006); Harvey G., et al, (2010); Sandhu M.S., et al, (2011), but more specific research on work performance and influencing factors have not been widely studied. The management practice under study still leads to management in general and leads to communication skills, interpersonal skills, analytical skills, technical skills, organizational skills and planning, creativity, innovation, leadership (also appears in A Gurtoo (2009)), responsibility And adaptability. Meanwhile, strategic management related to employees in an organization is still very little studied. Strategic management in an organization has an important role in an organization (Taufiqurokhman, 2016).

The problems of factors related to employee performance in organizations that exist in Indonesia have not been much studied, especially in organizations engaged in education, especially education under the auspices of Muhammadiyah. This study examines the effects of strategic management on work performance, organizational commitment and organizational culture on job performance, and the influence of strategic management and organizational commitment to employee performance.

\section{Methodology}

\subsection{Measures}

The sample used in the calculation of cluster sampling probability proportionate to size model (PPS) with the formulation of Slovin (Letoya P.S. \& Omwenga J., 2016) obtained 386 employees at 12 muhammadiyah universities in Indonesia. The developed instrument combines part of the existing questionnaire related to strategic management, organizational commitment, and job performance, 
using a Likert scale ranging from one to five using the Method of Successice Interval (MSI) (Riduwan, 2007).

The strategic management questionnaire was made with guided questionnaires once used by Wheelen, T. L. \& Hunger J. D., (2012) with a total of 28 questionnaires. Measurement of each statement with five Likert scales, ie ( 1 = very unsatisfactory, 5 = very satisfactory), with Cronbach $\mathrm{s}$ Alpha value of 0.958 .

Organizational commitment questionnaire, created by modifying questionnaires used by In'am, (2009) consisting of three dimensions of affective, continuity, and normative. Number of questionnaire items as many as 18 items of questionnaire. Likert scale size, ie $1=$ strongly disagree, up to $5=$ strongly agree. With Cronbach's Alpha value of 0.903 .

Organizational culture questionnaire, adopted Questionnaire used by Hofstede, et.al., (2010). The item is 8 items. Likert scale size, ie $1=$ strongly disagree, up to $5=$ strongly agree. With Cronbach's Alpha value of 0.937 .

Employee performance questionnaire was made with the adaptation of the Sayles questionnaire. L.R \& Strauss. G, (1980) with the number of items 25 questionnaires with five Likert scales, ie $1=$ strongly disagree, up to $5=$ strongly agree. Item of work achievement questionnaire totaling 25 items with Cronbach's Alpha of 0.970. The variables studied and the research setting are strategic management $\left(\mathrm{X}_{1}\right)$, organizational commitment $\left(\mathrm{X}_{2}\right)$, organizational culture $\left(\mathrm{X}_{3}\right)$ and work

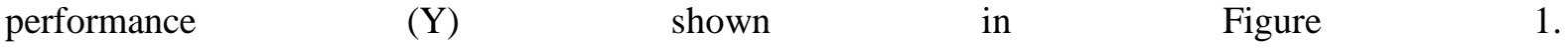

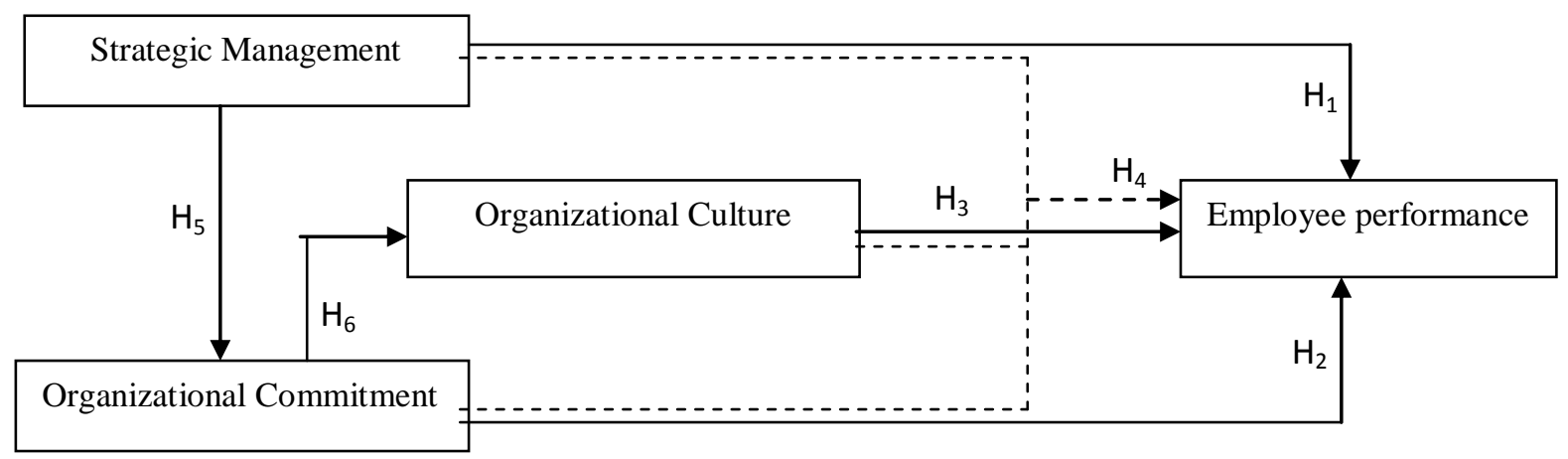

Figure 1. Research framework

\subsection{Data analysis}

The data were analyzed by regression equation using SPSS 17 software. The regression equation is used to determine the prediction of how high the predictor variable value to the dependent variable (Sugiyono, 2014). The use of regression analysis to test the hypothesis can be used if it meets five classical underlying assumptions, namely normality, multicollinearity, heteroscedasticity, autocorrelation and linearity (Gujarati, 2011). Further testing hypothesis in this study using the F test, $\mathrm{T}$ test and Coefficient of Determination Test (R2)

\section{Analysis of Results}

The results of data calculations obtained normality data from all variables each is normal. The data obtained then tested the hypothesis with the results shown in Table 1.

Table 1. The results of statistical calculations of research data

\begin{tabular}{|c|c|c|c|c|c|c|c|c|}
\hline \multirow{3}{*}{ NILAI } & \multicolumn{8}{|c|}{ VARIABEL } \\
\hline & \multirow{2}{*}{$X_{1}-Y$} & \multirow{2}{*}{$X_{2}-Y$} & \multirow{2}{*}{$X_{3}-Y$} & \multirow{2}{*}{$X_{1}-X_{2}$} & \multirow{2}{*}{$X_{2}-X_{3}$} & \multicolumn{3}{|c|}{$\mathrm{X}_{1}, \mathrm{X}_{2} \cdot \mathrm{X}_{3^{-}} \mathrm{Y}$} \\
\hline & & & & & & $\mathrm{X}_{1}$ & $\mathrm{X}_{2}$ & $X_{3}$ \\
\hline$\beta$ & 0.141 & 0.415 & 0.152 & 0.141 & 0.281 & 0.113 & 0.330 & 0.086 \\
\hline t- $\operatorname{arch}$ & 5.668 & 16.157 & 21.412 & 12.905 & 13.753 & 3.179 & 4.763 & 2.013 \\
\hline
\end{tabular}




\begin{tabular}{lllllllll} 
Sig $(\alpha)$ & 0.000 & 0.000 & 0.000 & 0.000 & 0.000 & 0.002 & 0.000 & 0.045 \\
Konstan & 48.801 & 76.686 & 90.985 & 48.801 & 77.716 & 57.203 & 57.203 & 57.203 \\
$\mathrm{R}^{2}$ & 0.061 & 0.089 & 0.031 & 0.076 & 0.031 & 0.127 & 0.127 & 0.127 \\
Adjusted & 0.058 & 0.087 & 0.028 & 0.074 & 0.028 & 0.121 & 0.121 & 0.121 \\
$\mathrm{R}^{2}$ & & & & & & & & \\
F-Test & 25.228 & 12.329 & 12.330 & 32.126 & 12.329 & 18.848 & 18.848 & 18.848 \\
DW & 1.396 & 1.344 & 1.346 & 1.822 & 1.898 & 1.354 & 1.354 & 1.354 \\
Tolerance & 1.000 & 1.000 & 1.000 & 1.000 & 1.000 & 0.894 & 0.938 & 0.938 \\
VIF & 1.000 & 1.000 & 1.000 & 1.000 & 1.000 & 1.119 & 1.066 & 1.099 \\
Level \% & $6.1 \%$ & $3.1 \%$ & $8.9 \%$ & $10.6 \%$ & $7.6 \%$ & & $7.6 \%$ & \\
\hline
\end{tabular}

The value of $F$ arithmetic is greater than the value of $F$ table based on the df value of 2,628 and the significance value is smaller than the probability value 0.05 then it shows that the independent variable simultaneously affect the dependent variable and vice versa (Leandre R. et al, 2012) . Similarly, the fact obtained from the comparison of the value of significance to the probability value where the value of significance is smaller than the probability value it can be concluded that the independent variables simultaneously affect the dependent variable and vice versa.

$\mathrm{T}$ test results for all veriabel respectively concluded that there is no significant difference between the variables $X_{1}, X_{2}$ and $X_{3}$ against $Y, X_{1}$ against $X_{2}, X_{2}$ against $X_{3}$ and $X_{1}, X_{2}$ and $X_{3}$ together to $\mathrm{Y}$.

The result of $t$ test for all veriabel of each Muhammadiyah Higher Colleges concluded that there is a significant difference between strategic management, organizational commitment, and organizational culture collectively towards employee performance.

Based on the calculation by using linear regression then obtained the formulation of the influence of one variable with another variable that is for variable $\mathrm{X}_{1}$ to $\mathrm{Y}$ that is $\mathrm{Yi}=48.801+0.141 \mathrm{X} 1$, variable $\mathrm{X}_{2}$ to $\mathrm{Y}$ that $\mathrm{Y}=76.686+0.415 \mathrm{X}_{2}$, variable $\mathrm{X}_{2}$ to $\mathrm{Y}$ that $\mathrm{Yi}=90985+0.152 \mathrm{X}_{1}, \mathrm{X}_{1}$ to $\mathrm{X}_{2}$ variable $\mathrm{X}_{2}=48.801+0.141 \mathrm{X}_{1}$ and variable $\mathrm{X}_{1}, \mathrm{X}_{2}$ to $\mathrm{Y}$ ie $\mathrm{Y}=57.203+0.113 \mathrm{X}_{1}+0.330 \mathrm{X}_{2}+$ $0.086 \mathrm{X}_{3}$, (Mooi. \& Sarstedt M, 2011).

\section{Discussion and Conclusion 4.1 Discussion}

Based on the findings of research on hypothesis testing obtained strategic management influence on employee performance. This indicates that strategic management has an effect on employee performance. Results of parallel research findings with research by Baharuddin \& Mulyono, (2006) which states significant improvement by using various strategies. Also supported by Yeewae's (2011) study, which stated that strategic management has a significant influence on teacher work performance, innovative treatment and principal support. The results of the research (Naserinajafabady, R, et al, 2013) that investigate in reverse conclude that the human resource strategy in the organization positively influences employees and prevents conflicts within the organization. Strategic management plays a role to make employees aware of the mission and goals of the organization and also improve employee performance improve organizational effectiveness. Based on the results of data analysis and discussion that has been explained then it can be concluded that strategic management has a positive influence on employee performance.

Research findings obtained organizational commitment affect the performance of employees. This shows that organizational commitment has an effect on employee performance. The findings of this research are parallel to Prasetyono \& Kompyurini's research. N, (2008) which suggests that organizational commitment has a positive and significant impact on performance in strong categories. The commitment of an employee to his organization can be an important instrument for improving the performance of the employee (Khan, 2010). Supported also by Murdiyani research, (2010) states workload, job satisfaction and organizational commitment affect the performance of permanent employees. Based on the results of data analysis and discussion that has been explained then it can be concluded that organizational commitment also affects the performance of employees. The results are also supported by Giri E.E, Nimran U, Hamid. D, \& Musadieq M.A., (2016) which concluded that organizational commitment has a significant effect on employee performance. Meanwhile, Habib. S, et al, (2014) states that organizational culture has a strong and profound impact on employee 
performance, which helps employees to be complacent with the organization thereby increasing the productivity of employees.

Based on the research findings obtained that the organizational culture affects the performance of lecturer work. Also supported by Cuong research, D. M \& Swierczek F. W., (2008) stated that corporate culture has a significant positive effect on performance. This means that if the organizational culture is improved, it will improve the performance of lecturer work. Also supported by opinion (Giri E.E, et al, 2016) which concluded that organizational culture has a significant effect on employee performance.

Also supported by (Awadh A.M. \& Saad A.M., 2013) states the values and norms of the organization based on employee relations. The goal of an organization is to improve the level of performance by designing a strategy. A strong organizational culture based on managers and leaders helps to increase the potential ability of organizations to compete. Managers link performance and organizational culture to each other as they help provide a competitive edge for the company.

The results of research calculations on hypothesis testing obtained strategic management influence on organizational commitment. The findings of this study are in line with Paşaoğlu's (2015) research findings, which suggest that HR management practices have an effect on commitment to a single organization in a single and systematic way. The results obtained by the new direction open in maintaining the consolidation of human resource management practices in the banking industry. The results showed that strategic management significantly influences organizational commitment. Meanwhile, Şendoğdu, A., et al, (2013) also stated that there is a strong and positive statistical relationship between other HRM variables and organizational commitment. Giauque, D., et al, (2010), reveals that organizational support, procedural justice and organizational reputation can clearly affect the commitment of knowledgeable employees, while other HRM practices such as engagement in decision making, management skills or satisfaction levels with salaries that do not have Nothing impacts on the commitment of knowledgeable employees.

Based on the research findings obtained that organizational commitment affect the organizational culture. The findings of this research are in line with the findings of Syaifuddin's research (2012) which suggests that the implementation of organizational commitment has an effect on organizational culture,

In accordance with the conclusion of the Miti penelitian research. S, et al, (2016) states that there is a statistically significant correlation between a particular dimension of organizational culture and the dimension of organizational commitment. Also, there is a statistically significant predictor effect of a particular dimension of organizational culture on the dimensions of organizational commitment.

According to Meyer, JP, et al, (2010), organizational commitment to employees can be enhanced by changing the organizational culture to positive and positive organizational culture. This is very useful to apply in terms of organizational change. Similarly, change-that leadership behavior has a positive relationship with organizational commitment (Özşahin, M., et al, 2013). According to Ellinger, AE, et al, (2013) undertakes a social capital investment organization that positively affects organizational commitment, work performance, and employee behavior. In addition, peer support has a different effect on organizational commitment, all of which depends on organizational culture (Limpanitgul, T., et al, 2014).

At the level of each condition, Organizational commitment is correlated with cultural values, such as individualism / collectivism (Meyer, JP, et al, 2012). Collective values have a modest influence on the relationship between people's commitment and organization level (Wasti, SA, \& Ca, Ö., 2008). This is in accordance with the results of Jaramillo's research, F., et al, (2005), where he showed that the correlation between organizational commitment and work performance was stronger in collectivists than in individualistic cultures. Also, during the process new product development often comes to increase organizational commitment, as stated especially in collective culture (Liang, B., et al, 2014).

Testing hypotheses analyzed obtained strategic management, organizational commitment and organizational culture, together affect the employee performance. This shows that strategic management, and organizational commitment and strategic management, and organizational commitment together affect the performance of employees. The findings of parallel research with Wiratno's research. A., et al, (2010) summarizes organizational culture, leadership style, organizational commitment and internal control influences Positive and significant to performance. 
Organizational culture, style of leadership, organizational commitment, coach handling and implementation of good government Simultaneously influence Positive and significant to Performance. Based on the research findings, it can be concluded that there is a significant influence between strategic management on organizational commitment, there is a significant influence between strategic management on organizational culture, there is a significant influence between management strategy on employee performance, there is a significant influence between organizational commitment to culture Organization, there is a significant influence between organizational commitment to employee performance, there is a significant influence between organizational culture on employee performance, and together there is a significant influence between strategic management, organizational commitment, organizational culture on employee performance in Higher Education Muhammadiyah . The results are also supported by research from Giri E.E, et al, (2016) stating that 1). Job involvement has a significant influence on organizational commitment; Job involvement has no significant influence on knowledge sharing; And job involvement has a significant effect on employee performance. 2). Organizational commitment has a significant influence on knowledge sharing; And organizational commitment has a significant influence on worker achievement, 3) Knowledge sharing has a significant effect on worker achievement.

\subsection{Conclusion}

The results concluded that

1. strategic management of organizational and cultural commitment affect the employee performance,

2. Strategic management affects organizational commitment,

3. Organizational commitment affects the organizational culture

4. strategic management, organizational commitment and organizational culture, together affect the employee performance.

Strategic management, organizational commitment, organizational culture and employee performance have mutual interrelationships and mutual influence.

\section{Reference}

A. Iqbal, M. Ijaz, F. Latif \& H. Mushtaq. (2015). Factors Affecting The Employee's Performance: A Case Study Of Banking Sector In Pakistan. European Journal Of Business And Social Sciences , 4 (8), 309-318.

Ahuja, K. (2006). Personnel management. 3rd Ed. New Delhi. India: Kalyani publishers.

Akhtar, S., \& Tan, D. (1994). Reassessing and reconceptualizing the multidimensional nature of organizational commitment. Psychological Reports , 75 (3), 1379.

Allen, N.J., \& J.P. Meyer. (1990). The Measurement and Antecedents of Affective, Continuance, and Normative Commitment to the organization. Journal of Occupational Psychology , 63 (1), 118.

Allen, Natalie J., John P. \& Meyer. A. (1991). Three Component Conceptualization of Organizational Commitment. Human Resource Management Review , 1 (1), 61 - 89.

Armstrong, M. (2000). A handbook of personnel Management Practices. London: Kogan Page Limited.

Awadh. A.M. \& Saad. A.M. (2013). Impact of Organizational Culture on Employee Performance. International Review of Management and Bunsiness Research , 2 (1), 168-175.

Baharuddin \& Mulyono. (2006). Manajemen Strategik Peningkatan Kinerja Dosen Perguruan Tinggi Agama Islam (Studi Kasus di UIN Malang). Retrieved November 28, 2016, from ejournal.uinmalang.ac.id: http://ejournal.uin-malang.ac.id/index.php/lemlit/article/view/2026/pdf

Bateman, T. S., \& Strasser, S. (1984). A longitudinal analysis of the antecedents of organizational commitment. Academy of Management Journal, , 27, 95-112.

Bentein, K., Vandenberghe, C., Vandenberg, R., \& Stinglhamber, F. (2005). The role of change in the relationship between commitment and turnover: A latent growth modeling approach. Journal of Applied Psychology , 90 (3), 468-482.

Bowen ,D. E., \& Ostroff, C. (1989). Understanding HRM-firm performance linkages: The role of "Strength" of the HR system. Academy of Management Review , 29, 203-220. 
Brooks, I. (2006). Organizational Behavior: Individuals, Groups and Organization. Essex: Pearson Education Limited.

Bryson, J. M., F. Ackermann, and C. Eden. (2007). Putting the Resource Based View of Strategy to Work in Public Organizations. Public Administration Review , 67 (4), 702-717.

Cavus. M.F \& Saracoglu. T. (2014). Human Resource Management Practices, Job Satisfaction and Organizational Commitment. International Journal of Academic Research in Business and Social Sciences , 4 (9), 178-190.

Chan, D. (2006). Core Competencies And Performance Management In Canadian Public Libraries. Library Management, 27 (3).

Cuong, D. M \& Swierczek F. W. (2008). Corporate Culture, Leadership Competencies, Job Satisfaction, Job Commitment, and Job Performance: A Comparison of Companies in Vietnam and Thailand. The Journal of American Academy of Business Cambridge , 13 (1), 59-165.

Daft, L. (1988). Management. First Edition. Chicago, New York: The Dryden press.

David, F. (2005). Strategic Management: Concepts and Cases, Tenth Edition. Prentice Hall: Pearson Education International.

Dess, Gregory G., G.T. Lumpkin and Marilyn L. Taylor. (2005). Strategic Management. 2 ed. New York: McGraw-Hill Irwin.

Dharmanegara. I.B.A, Sitiari1. N.W, \& Adelina. M.E. (2016). The Impact of Organizational Commitment, Motivation and Job Satisfaction on Civil Servant Job Performance in State Plantation Denpasar. IOSR Journal of Business and Management (IOSR-JBM) , 18 (2), 41-50.

Ellinger, AE, Musgrove, CF, Ellinger, AD, Bachrach, DG, Baş ABE, \& Wang, YL. (2013). Influences of organizational investments in social capital on service employee commitment and performance. Journal of Business Research , 8, 1124-1133.

Ferris, G. R., Arthur, M. M., Berkson, H. M., Kaplan, D. M., Harrell-Cook, G., \& Frink, D. D. (1998). Toward a social context theory of human resource management- organizational effectiveness relationship. Human Resource Management Review , 8, 235-264.

Field, A. (2013). Discovering Statistics using IBM SPSS Statistics. SAGE: Singapore.

Giauque, D., Resenterra F., \& Siggen M. (2010). The relationship between HRM practices and organizational commitment of knowledge workers: Facts obtained from Swiss SMEs. Human Resource Development International , 13 (2), 185-205.

Giri E.E, Nimran U, Hamid. D, \& Musadieq M.A. (2016). The Effect of Organizational Culture and Organizational Commitment to Job Involvement, Knowledge Sharing, and Employee Performance: A Study on Regional Telecommunications Employees of PT Telkom East Nusa Tenggara Province, Indonesia. International Journal of Management and Administrative Sciences (IJMAS) , 3 (4), 20-33.

Goel A., Rana G., Rastogi R. (2010). Knowledge Management as a Process to Develop Sustainable Competitive Advantage. South Asian Journal of Management , 17 (3).

Gujarati, D. (2011). Econometrics by Example. New York: Palgrave macmillan.

Gurtoo, A. (2009). Adaptation Of Indian Public Sector To Market-Based Economic Reforms. A Resource-Based Perspective. International Journal of Public Sector Management, 22 (6).

Habib. S, Aslam. S, Hussain. A, Yasmeen. A, \& Ibrahim. M. (2014). The Impact of Organizational Culture on Job Satisfaction, Employess Commitment and Turn over Intention. Advances in Economics and Business , 2 (6), 215-222.

Hanaysha, J. (2016). Examining the Effects of Employee Empowerment, Teamwork, and Employee Training on Organizational Commitment. Procedia - Social and Behavioral Sciences , 229 (298 - 306), $298-306$.

Harvey G., Skelcher Ch., Spencer E., Jas P., Walshe K. (2010). Absorptive capacity in a non-market environment. A knowledge-based approach to analysing the performance of sector organizations. Public Management Review, 12 (1).

Hashim, M. K. (2005). Strategic Management. Singapore: Thomson Learning.

Hassan, S. (2016). Impact of HRM Practices on Employee's Performance. International Journal of Academic Research in Accounting, Finance and Management Sciences , 6 (1), 15-22.

Hellriegel, D. \& Slocum, J. M. (2009). Organizational Behavior (9th Edition). Sydney: Thomson Learners.

Hellriegel, D., \& Slocum, J. M. (2007). Organizational Behavior. South- Western U.S.A. 
Hofstede, et.al. (2010). Cultures and Organizations. New York: Mc Graw Hill.

In'am, A. (2009). Analisis Pelaksanaan Kebijakan Pemberdayaan Guru Sekolah Menengah Pertama Negeri di Indonesia. Kuala Lumpur: University of Malaya Faculty of Education.

Jaramillo, F., Mulki, JP, \& Marshall, GW. (2005). A meta-analysis of the relationship between organizational commitment and salesperson job performance: 25 years of research. Journal of Business Research , 58 (6), 705-714.

Karim, F., \& Rehman, O. (2012). Impact of job satisfaction, perceived organizational justice and employee empowerment on organizational commitment in semi-government organizations of Pakistan. Journal of Business Studies Quarterly , 3 (4), 92-104.

Kenney et al. (1992). Management Made East. 1st Ed. South Carolina: Omron Publishers.

Khan, M. (2010). The Impact of Organizational Commitment on Employee Job Performance. European Journal of Social Sciences , 15 (3), 292-298.

Kinicki, A. \& Kreitner, R. (2007). Organizational Behavior. New York: McGraw-Hill.

Kotler, P. \& Armstrong, G. (2002). Marketing: An introduction. 6th Ed. London: Prentice-Hall.

Kotter, J. P., \& Heskett, J. L. (1992). Corporate Culture and Performance. New York: Free Press.

Leandre R. Fabrigar, Duane T. Wegener. (2012). Exploratory Factor Analysis. New York: Oxford University.

Letoya. P.S. \& Omwenga. J. (2016). Factors Affecting Utilization of Evaluations in Selected NonProfit Organizations in Kenya. International Journal of Entrepreneurship and Project Management, 1 (2).

Liang, B., Kale, SH, \& Cherian, J. (2014). Is the future static or dynamic? The role of culture on escalation of commitment in new product development. Industrial Marketing Management , 43 (1), 155-163.

Limpanitgul, T., Boonchoo, P., \& Photiyarach, S. (2014). Coworker support and organisational commitment: A comparative study of Thai employees working in Thai and American airlines. Journal of Hospitality and Tourism Management, 21, 100-107.

Lumley, E., Coetzee, M., Tladinyane, R., \& Ferreira, N. (2011). Exploring the job satisfaction and organisational commitment of employees in the information technology environment. Southern African Business Review , 15 (1), 100-118.

Magee, K. C. (2002). The impact of organizational cultureon the implementation of performance management(Doctoral dissertation). Available from Dissertations and Theses database (UMI No.3047909). .

Martin,J. \& Siehl, C. . (1990). Organizational Culture: A Key to Financial Performance. In B.Schneider (ed.). Organizational Climate and Culture. San Francisco: CA: Jossey-Bass.

Mathew, J. (2007). The relationship of organizational culture with productivity and quality: A study of Indian software organizations. Employee Relations , 29 (6), 677-695.

Meyer, J.P. \& Allen, N.J. (1997). Commitment in the Workplace: Theory, Research, and Application. Thousand Oaks: Sage.

Meyer, J.P., \& Allen, N.J. (1991). A three-component conceptualization of organizational commitment. Human Resource Management Review , 1 (1), 61-89.

Meyer, JP, Hecht, TD, Gill, H., \& Toplonytsky, L. (2010). Person-organization (culture) fit and employee commitment under conditions of organizational change: A longitudinal study. Journal of Vocational Behavior, 76 (3), 458-473.

Meyer, JP, Stanley, DJ, Jackson, TA, McInnis, KJ, Maltin, ER, \& Sheppard, L. (2012). Affective, normative, and continuance commitment levels across cultures: A meta-analysis. Journal of Vocational Behavior, 80 (2), 225-245.

Mitić. S, Vukonjanski. J, Terek. E, Gligorović. B, \& Zorić K. (2016). Organizational Culture And Organizational Commitment: Serbian Case. Journal Of Engineering Management And Competitiveness (Jemc) , 6 (1), 21-27.

Mohamed, Z. A. (2005). Pengurusan Strategik. Siri Pengurusan dan Pentadbiran Utusan. Kuala Lumpur: Utusan Publications \& Distributors Sdn. Bhd.

Mooi. E \& Sarstedt. M. (2011). A Concise Guide to Market Research: The Process, Data, and Methods Using IBM SPSS Statistics. Springer Science \& Business Media. 
Muogbo, U. .. (2013). The Impact of Strategic Management on Organisational Growth and Development (A Study of Selected Manufacturing Firms in Anambra State). IOSR Journal of Business and Management (IOSR-JBM) , 7 (1), 24-32.

Murdiyani, H. (2010). Pengaruh Beban Kerja, Kepuasan Kerja Dan Komitmen Organisasi Terhadap Kinerja Dosen Tetap; (Studi Kasus Di Fakultas Ilmu Kesehatan Universitas Muhammadiyah Surabaya). Surakarta: Program Pascasarjana Universitas Sebelas Maret Surakarta.

Naserinajafabady. R, Hassan Rangriz. H, \& Mehrabi. J. (2013). Effects of organizational culture, structure and strategy on organizational effectiveness by using knowledge management Case Study: Seven International Transportation Company. International Research Journal of Applied and Basic Sciences , 7 (6), 355-361.

Özşahin, M., Zehir, C., Acar AZ, \& Sudak, MK. (2013). The Effects of Leadership and Market Orientation on Organizational Commitment. Social and Behavioral Sciences , 99 (6), 363-372.

Paşaoğlu, D. (2015). Analysis of the Relationship Between Human Resources Management Practices and Organizational Commitment from a Strategic Perspective: Findings from the Banking Industry. Procedia - Social and Behavioral Sciences , 315 - 324.

Peters, T. J., \& Waterman, R. H. (1982). In Search of Excellence. New York: NY: Harper \& Row.

Prasetyono \& Kompyurini. N. (2008). Analisis Kinerja Rumah Sakit Daerah Berdasarkan Budaya Organisasi, Komitmen Organisasi Dan Akuntabilitas Publik (Survei Pada Rumah Sakit Daerah di Jawa Timur). Simposium Nasional Akuntansi 11. IAI. Pontianak.

Qureshi, J.A., Hayat, K., Ali, M., \& Sarwat, N. (2011). Impact of job satisfaction and organizational commitment on employee performance, evidence from Pakistan. Interdisciplinary Journal of Contemporary Research in Business, 3 (4), 642-657.

Raduan, C.R., Jegak, U., Haslinda, A. And Alimin, I.I. (2009). Management, Strategic Management Theories and the Linkage with Organisational Competitive Advantage from the ResourceBased View. European Journal of Social Sciences , 11 (3), 402- 418.

Sackmanns, S. A. \& Bertelsmann S. (2006). Success Factor Corporate Culture. Developing a Corporate Culture for High Performance and Longterm Competitiveness Six Best Practices. Kinndle Edition.

Sahoo, C. K., Behera, N., \& Tripathy, S. K. (2010). Employee empowerment and individual commitment: an analysis from integrative review of research. Employment Relations Record, , $10(1), 40-56$.

Sahoo. C.K \& Das. S. (2011). Employee Empowerment: A Strategy towards Workplace Commitment. European Journal of Business and Management , 3 (11), 46-54.

Sandhu M.S., Jain K.K., Kalthom bte Ahmad J.I. (2011). Knowledge Sharing Among Public Sector Employees: Evidence From Malaysia. International Journal of Public Sector Management , 24 (3).

Sayles. L.R \& Strauss. G. (1980). Strauss' \& Sayles' Behavioral Strategies for Managers. United States: Prentice Hall.

Schein, E. M. (2004). Organizational culture and leadership (3rd ed.). New York: Jossy-Bass.

Şendoğdu, A., Kocabacak, A., \& Güven, Ş. . (2013). The relationship between human resource management practices and organizational commitment: A field study. Social and Behavioral Sciences , 818-827.

Shaw, J.D., Delery, J.E., \& Abdulla, M.H. (2003). Organizational commitment and performance among guest workers and citizens of an Arab country. Journal of Business Research, , 56 (12), 1021-1030.

Shouksmith., G. (1994). Variables related to organizational commitment in health professionals. Psychological Reports , 74 (3), 707-711.

Stoner, J. A. F., Freeman, E. \& Gilbert, D. A. (1995). Management. 6th Ed. London: Prentice-Hall International.

Stoner, J. A. (1996). Management. 6th Ed. Pearson Education.

Sugiyono. (2014). Metode Penelitian Kuantitatif Kualitatif dan $R \& D$. Bandung: Alfa Beta.

Syaifuddin. (2012). Pengaruh Faktor-faktor Manajerial terhadap Budaya Organisasi serta Implikasinya pada Kinerja Manajerial. Trikonomika , 11 (1), 58-68.

Taufiqurokhman. (2016). Mengenal Manajemen Strategik. Jakarta: Fakultas Ilmu Sosial dan Ilmu Politik Universitas Prof. Dr. Moestopo Beragama. 
Tharp, B. M. (2009). Four Organizational Culture Types. Organizational Culture White Paper.

Uddin M.J, Luva R.H \& Hossian. S.M.M. (2013). Impact of Organizational Culture on Employee Performance and Productivity: A Case Study of Telecommunication Sector in Bangladesh. International Journal of Business and Management , 2, 63-77.

Wasti, SA, \& Ca, Ö. (2008). Affective and normative commitment to organization, supervisor, and coworkers: Do collectivist values matter? Journal of Vocational Behavior , 73 (3), 404-413.

Wheelen, T. L. \& Hunger J. D. (2012). Strategic Management and Business Policy (13th edition). New Jersey: Pearson Education.

Wiratno. A., Pratiwi. U., \& Nurkhikmah. (2010). Pengaruh Budaya Organisasi, Gaya Kepemimpinan, Komitmen Organisasi Dan Pengendalian Intern Terhadap Penerapan Good Governance Serta Implikasinya Pada Kinerja (Survey Pada Kantor Pelayanan Perbendaharaan Negara Tegal). Fakultas Ekonomi Universitas Jenderal Soedirman.

Yeewae, M. (2011). Pengaruh Amalan Pengurusan Strategik, Sokongan Pengetua Dan Perlakuan Inovatif Terhadap Prestasi Kerja Guru Sekolah Agama Rakyat Di Wilayah Yala, Thailand. Retrieved November 28, 2016, from eprints.usm.my: http://eprints.usm.my/29913/1/Mayeng_Yeewae.pdf

Zafar. F, Babar. S \& Abbas. H. (2013). The Art Of Strategic Management- A Key To Success In Corporate Sector. European Journal of Research and Reflection in Management Sciences , 1 (1).

Zangaro, G. (2001). Organisational commitment: A concept analysis. Nursing Forum , 36 (2), 14-21. 